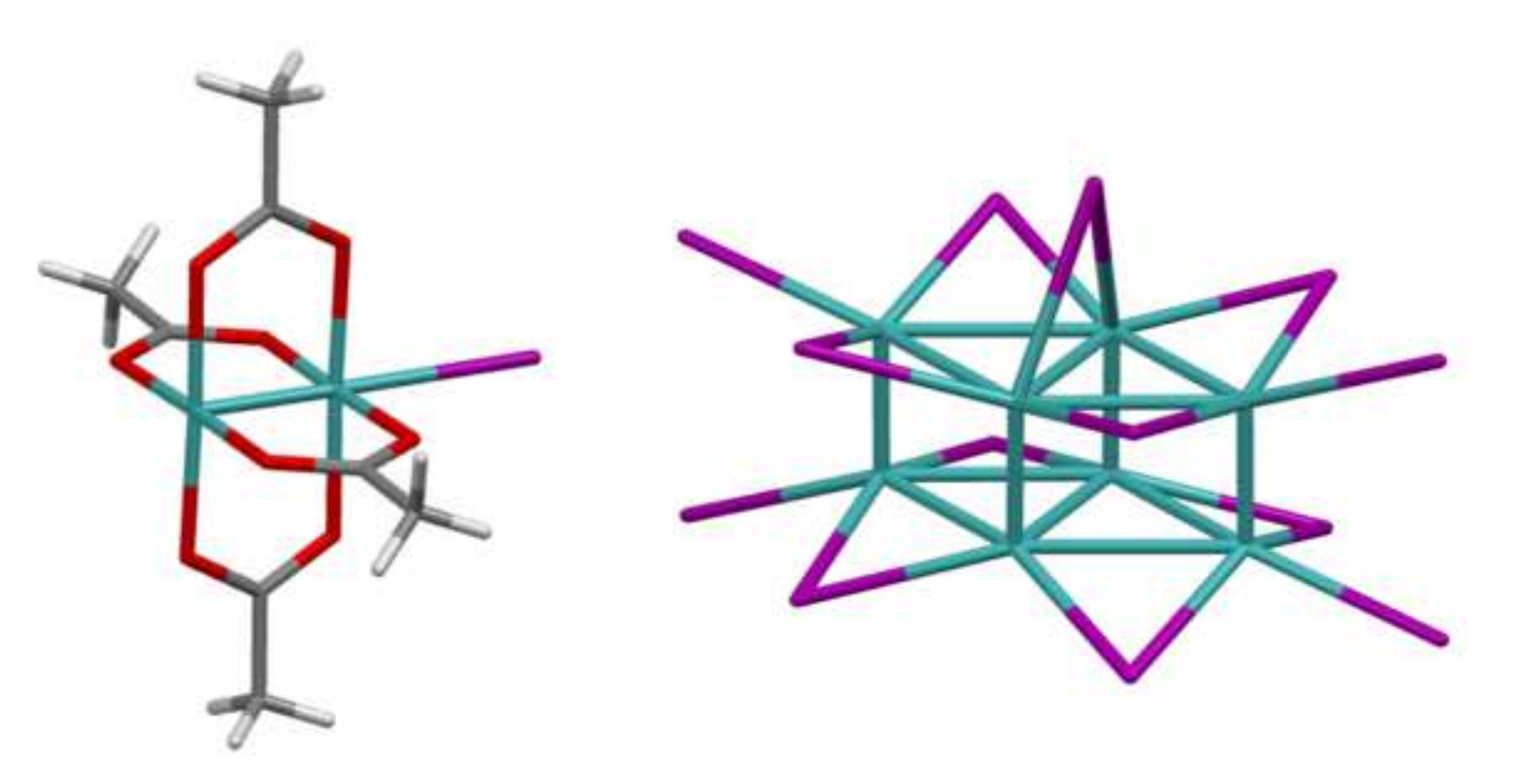


Graphical abstract

\section{Graphical Abstract}

Two new technetium iodide compounds, $\mathrm{Tc}_{2}\left(\mathrm{O}_{2} \mathrm{CCH}_{3}\right)_{4} \mathrm{I}$ and $\mathrm{KTc}_{8} \mathrm{I}_{13}$, were synthesized in an autoclave from the reaction of $\mathrm{KTcO}_{4}$ in glacial acetic acid with hydroiodic acid and/or alkali metal iodide salts at $210^{\circ} \mathrm{C}$ under 60-70 atm hydrogen. The structures of $\mathrm{Tc}_{2}\left(\mathrm{O}_{2} \mathrm{CCH}_{3}\right)_{4} \mathrm{I}$ and $\mathrm{KTc}_{8} \mathrm{I}_{13}$ were solved by singlecrystal X-ray diffraction. 


\title{
Hydrothermal Synthesis and Solid-State Structures of Polynuclear Technetium Iodide Compounds $^{\dagger}$
}

William M. Kerlin ${ }^{\mathrm{a}^{*}}$, Frederic Poineau ${ }^{\mathrm{a}}$, Paul M. Forster ${ }^{\mathrm{a}}$, Kenneth R. Czerwinski ${ }^{\mathrm{a}}$ and Alfred P. Sattelberger ${ }^{\mathrm{a}, \mathrm{b}}$

${ }^{a}$ Department of Chemistry, University of Nevada Las Vegas, Las Vegas, NV 89154.

${ }^{\mathrm{b}}$ Argonne National Laboratory, Argonne, IL 60439.

${ }^{\dagger}$ Dedicated to Professor John E. Bercaw, Caltech, on the occasion of his 70th birthday.

Keywords: Technetium compounds; Metal-metal interaction; Cluster compounds; Hydrothermal synthesis; Structure elucidation

\begin{abstract}
Two new technetium iodide compounds, $\mathrm{Tc}_{2}\left(\mathrm{O}_{2} \mathrm{CCH}_{3}\right)_{4} \mathrm{I}$ and $\mathrm{K}\left[\mathrm{Tc}_{8}(\mu-\mathrm{I})_{8} \mathrm{I}_{4}\right] \mathrm{I}$, were synthesized in an autoclave from the reaction of $\mathrm{KTcO}_{4}$ in glacial acetic acid with hydroiodic acid and/or alkali metal iodide salts at $210{ }^{\circ} \mathrm{C}$ under $60-70$ atm hydrogen pressure. The structures of $\mathrm{Tc}_{2}\left(\mathrm{O}_{2} \mathrm{CCH}_{3}\right)_{4} \mathrm{I}$ and $\mathrm{K}\left[\mathrm{Tc}_{8}\left(\mu-\mathrm{I}_{8} \mathrm{I}_{4}\right] \mathrm{I}\right.$ were solved by single-crystal X-ray diffraction. The compound $\mathrm{Tc}_{2}\left(\mathrm{O}_{2} \mathrm{CCH}_{3}\right)_{4} \mathrm{I}$ crystallizes in the monoclinic space group $\mathrm{C} 2 / \mathrm{m}$ with $a=7.1194(6)$ $\AA, b=14.5851(13) \AA, c=7.1586(6) \AA$, and $\beta=110.9540(10)^{\circ}$. The structure of $\mathrm{Tc}_{2}\left(\mathrm{O}_{2} \mathrm{CCH}_{3}\right)_{4} \mathrm{I}$ consists of infinite chains of $\mathrm{Tc}_{2}\left(\mathrm{O}_{2} \mathrm{CCH}_{3}\right)_{4}{ }^{+}$units linked by bridging iodides, an arrangement similar to the one found in $\mathrm{Tc}_{2}\left(\mathrm{O}_{2} \mathrm{CCH}_{3}\right)_{4} \mathrm{X}(\mathrm{X}=\mathrm{Cl}, \mathrm{Br})$. The Tc-Tc separation in $\mathrm{Tc}_{2}\left(\mathrm{O}_{2} \mathrm{CCH}_{3}\right)_{4} \mathrm{I}$ (i.e., 2.1146(4) $\AA$ ) is consistent with the presence of a Tc-Tc bond of order 3.5. Magnetic susceptibility measurements reveal $\mathrm{Tc}_{2}\left(\mathrm{O}_{2} \mathrm{CCH}_{3}\right)_{4} \mathrm{I}$ to be paramagnetic ( $\mu_{\text {eff }}=1.84$ B.M.) and support the electronic configuration $\sigma^{2} \pi^{2} \delta^{2} \delta^{* 1}$ for the $\mathrm{Tc}_{2}{ }^{5+}$ unit in the compound. The compound $\mathrm{K}\left[\mathrm{Tc}_{8}\left(\mu-\mathrm{I}_{8} \mathrm{I}_{4}\right] \mathrm{I}\right.$ crystallizes in the monoclinic space group $\mathrm{P} 2_{1} / \mathrm{n}$ with $a=8.0018(5) \AA$, $b=14.5125(10) \AA, c=13.1948(9) \AA$, and $\beta=102.3090(10)^{\circ}$, and is the first octanuclear technetium iodide cluster to be reported. The Tc-Tc separations in the $\left[\operatorname{Tc}_{8}(\mu-\mathrm{I})_{8} \mathrm{I}_{4}\right]$ cluster (i.e., 2.164(3) $\AA$, 2.5308(8) $\AA$ and 2.72(3) $\mathrm{A}$ ) suggest the presence of $\mathrm{Tc} \equiv \mathrm{Tc}$ triple bonds, $\mathrm{Tc}=\mathrm{Tc}$ double bonds and Tc-Tc single bonds.
\end{abstract}




\section{Introduction}

Transition metal compounds with metal-metal multiple bonds play an important role in inorganic, materials, bioinorganic and organometallic chemistry. Studies of their molecular and electronic structures are essential to understanding their catalytic biological properties as well as the nature of metal-metal interactions in those materials. ${ }^{[1]}$ Technetium metal-metal bond chemistry remains underdeveloped compared to its neighboring elements - molybdenum, ruthenium and rhenium. $^{[2 \mathrm{a}-\mathrm{d}]}$ As of the year 2005, 25 dinuclear species, 4 hexanuclear, 6 octanuclear halide clusters and 3 extended metal-atom chain (EMAC) compounds containing TcTc multiple bonds had been structurally characterized. While halide ions such as the well-known $\mathrm{Tc}_{2} \mathrm{Cl}_{8}{ }^{2-}$ ion are well-described, no binary halides with multiple metal-metal bonds had been reported. ${ }^{[3]}$ As part of an effort to expand our knowledge of technetium metal-metal bond chemistry, we prepared seven new binary halides $\left(\mathrm{TcBr}_{4}, \mathrm{TcBr}_{3}, \alpha / \beta-\mathrm{TcCl}_{3}, \alpha / \beta-\mathrm{TcCl}_{2}\right.$, and $\left.\mathrm{TcI}_{3}\right){ }^{[4-10]}$ The oxidation state of the Tc atom likely determines the extent to which Tc-Tc bonding occurs. In the tetrahalide $\mathrm{TcBr}_{4}$, there is no discernable metal-metal interaction. As the oxidation state drops, Tc-Tc bonding increases; a Tc=Tc double bond is observed in $\alpha / \beta-\mathrm{TcCl}_{3}$ and a $\mathrm{Tc} \equiv \mathrm{Tc}$ triple bond in $\alpha / \beta-\mathrm{TcCl}_{2}$.

Two main routes have proven fruitful for the synthesis of technetium binary halides: reaction between the elements in a sealed evacuated tube, $\left.{ }^{[5,} 6\right]$ and reaction between $\mathrm{Tc}_{2}\left(\mathrm{O}_{2} \mathrm{CCH}_{3}\right)_{4} \mathrm{Cl}_{2}$ and flowing $\mathrm{HX}$ gas $(\mathrm{X}=\mathrm{Cl}, \mathrm{Br}$, I) at elevated temperatures. Technetium trihalides $\left(\mathrm{TcBr}_{3}, \mathrm{TcI}_{3}\right.$ and $\left.\alpha-\mathrm{TcCl}_{3}\right)$ have been obtained from the reaction of $\mathrm{Tc}_{2}\left(\mathrm{O}_{2} \mathrm{CCH}_{3}\right)_{4} \mathrm{Cl}_{2}$ with HX gas at $300{ }^{\circ} \mathrm{C} .{ }^{[7,8]}$ Thus, new technetium metal-metal bonded dimers with carboxylate ligands are of particular interest as precursors for the preparation of new technetium binary halides, $\mathrm{TcX}_{\mathrm{y}}(\mathrm{X}=\mathrm{F}, \mathrm{Cl}, \mathrm{Br}, \mathrm{I} ; \mathrm{y}=2,3,4) .{ }^{[9,10]}$ The study of $\mathrm{Tc}_{2}\left(\mathrm{O}_{2} \mathrm{CCH}_{3}\right)_{2} \mathrm{Cl}_{4}$ also permitted to better understand the influence of acetate ligand on the Tc-Tc bonding. ${ }^{[11]}$ Currently, only five compounds containing $\mathrm{a} \mathrm{Tc}_{2}{ }^{\mathrm{n}+}(\mathrm{n}=5,6)$ units coordinated to acetate and halogen ligands are structurally characterized: $\mathrm{Tc}_{2}\left(\mathrm{O}_{2} \mathrm{CCH}_{3}\right)_{4} \mathrm{X}^{[12,13]}, \mathrm{K}\left[\mathrm{Tc}_{2}\left(\mathrm{O}_{2} \mathrm{CCH}_{3}\right)_{4} \mathrm{Cl}_{2}\right]$ and $\mathrm{Tc}_{2}\left(\mathrm{O}_{2} \mathrm{CCH}_{3}\right)_{4} \mathrm{X}_{2}(\mathrm{X}$ $=\mathrm{Cl}, \mathrm{Br}),{ }^{[14,15]}$ and no complexes with multiple metal-metal bonds coordinated to iodide ligands have been reported yet. The unknown $\mathrm{Tc}_{2}\left(\mathrm{O}_{2} \mathrm{CCH}_{3}\right)_{4} \mathrm{I}_{2}$ represents an important target, and it was expected that this compound could be obtained by the route used for the preparation of $\mathrm{Tc}_{2}\left(\mathrm{O}_{2} \mathrm{CCH}_{3}\right)_{4} \mathrm{Cl}_{2}$ (i.e., hydrogen reduction of $\mathrm{KTcO}_{4}$ in a mixture acetic acid/HCl). In this 
context, we performed the autoclave reduction of $\mathrm{KTcO}_{4}$ in acetic acid/MI media $(\mathrm{M}=\mathrm{Na}, \mathrm{K}, \mathrm{H})$ and report two new compounds: $\mathrm{Tc}_{2}\left(\mathrm{O}_{2} \mathrm{CCH}_{3}\right)_{4} \mathrm{I}$ and $\mathrm{K}\left[\mathrm{Tc}_{8}(\mu-\mathrm{I})_{8} \mathrm{I}_{4}\right] \mathrm{I}$. Here, we present the synthesis and solid-state structure of these compounds.

\section{Experimental Section}

\subsection{Starting materials}

Caution! Techetium-99 is a weak beta emitter $\left(E_{\max }=292 \mathrm{keV}\right)$. All manipulations were performed in a laboratory designed for chemical synthesis with radionuclides using efficient HEPA-filtered fume hoods, hydrothermal synthetic techniques, and following locally approved radioisotope handling and monitoring procedures. Laboratory coats, disposable gloves, and protective eyewear were worn at all times.

Ammonium pertechnetate, $\mathrm{NH}_{4} \mathrm{TcO}_{4}$, was purchased from Oak Ridge National Laboratory. It was purified and converted to $\mathrm{KTcO}_{4}$ by reaction with aqueous $\mathrm{KOH}$ and $30 \%$ $\mathrm{H}_{2} \mathrm{O}_{2}{ }^{[16]}$ Glacial acetic acid (>99.7\%), 57 wt. \% hydroiodic acid (> 99.95\%) distilled and stabilized with $<1.5 \%$ hypophosphorous acid, sodium iodide $(>99.5 \%)$, and potassium iodide (99\%) were purchased from Sigma Aldrich and used without further purification. Sodium borohydride (99.9\%) was obtained from Acros and used as received.

\subsection{Preparation of $\mathrm{Tc}_{2}\left(\mathrm{O}_{2} \mathrm{CCH}_{3}\right)_{4} \mathrm{I}$}

Route a. A 4 dram borosilicate glass vial of original dimensions $2.1 \times 7.0 \mathrm{~cm}$, inner diameter $1.8 \mathrm{~cm}$, was custom-cut to $3.5 \mathrm{~cm}$ in height. Potassium pertechnetate $(104.4 \mathrm{mg}, 0.517$ $\mathrm{mmol})$ and sodium iodide $(151.2 \mathrm{mg}, 1.01 \mathrm{mmol})$ were added to this vessel with a molar ratio of 1:2 technetium:iodide. The glass vial was placed in a $23 \mathrm{~mL}$ Teflon acid digestion autoclave (Parr Instruments) and $6.00 \mathrm{~mL}$ of glacial acetic acid was dispensed into the glass vial. To the Teflon autoclave, outside the glass vial, sodium borohydride $(322 \mathrm{mg}, 8.51 \mathrm{mmol})$ and $0.200 \mathrm{~mL}$ of deionized water was added. An illustration of the experimental autoclave setup is shown above in Figure 1. The system was sealed and placed in an oven at $210^{\circ} \mathrm{C}$ for 3 days. Sodium borohydride reacts with water and acid to generate hydrogen gas in situ. Complete reaction 
would result in approximately 60-70 atm of $\mathrm{H}_{2}$ pressure at $210{ }^{\circ} \mathrm{C}$. After 3 days, the autoclave was allowed to cool to room temperature on an aluminum block, and then opened in a sealed bag revealing well-formed, light brown crystals of $\mathrm{Tc}_{2}\left(\mathrm{O}_{2} \mathrm{CCH}_{3}\right)_{4} \mathrm{I}$. The mother liquor was removed by glass pipet, the product was washed with acetic acid $(2 \times 2 \mathrm{~mL})$, isopropyl alcohol $(2 \times 2 \mathrm{~mL})$, and diethyl ether $(2 \times 2 \mathrm{~mL})$, then dried in open air. Yield: $120.1 \mathrm{mg}(0.213 \mathrm{mmol}, 82.8 \%)$. Anal. Calcd. for $\mathrm{C}_{8} \mathrm{H}_{12} \mathrm{O}_{8} \mathrm{ITc}_{2}$ : Tc, 35.29; I, 22.62. Found: Tc, 35.08; I, 22.49. FT-IR (ATR, $\mathrm{cm}^{-}$ $\left.{ }^{1}\right)$ : 2916s $\left(v_{\mathrm{as}} \mathrm{CH}_{3}\right), 2848 \mathrm{~s}\left(v_{\mathrm{s}} \mathrm{CH}_{3}\right), 1459 \mathrm{~s}$ ( $\left.v_{\mathrm{as}} \mathrm{COO}\right), 1437 \mathrm{~s}$ ( $\left.v_{\mathrm{s}} \mathrm{COO}\right)$. The compound decomposes at $\sim 380^{\circ} \mathrm{C}$.

$\underline{\text { Route } b}$. The reaction was performed using the same procedure as the one described in route a. Potassium pertechnetate $(91.3 \mathrm{mg}, 0.452 \mathrm{mmol})$ and potassium iodide $(135.1 \mathrm{mg}, 0.814$ mmol) was added to the glass vial (Tc:KI molar ratio 1:2). The glass vial was placed in a 23 $\mathrm{mL}$ Teflon acid digestion autoclave and $6.00 \mathrm{~mL}$ of glacial acetic acid was dispensed into the glass vial. To the Teflon autoclave, outside the glass vial, sodium borohydride $(321 \mathrm{mg}, 8.49$ $\mathrm{mmol}$ ) and $0.200 \mathrm{~mL}$ of deionized water was added. The system was sealed and placed in an oven at $210^{\circ} \mathrm{C}$ for 3 days. After 3 days, the autoclave was allowed to cool to room temperature on an aluminum block, and opened. The mother liquor was removed by glass pipet, the brown product $\left(\mathrm{Tc}_{2}\left(\mathrm{O}_{2} \mathrm{CCH}_{3}\right)_{4} \mathrm{I}\right)$ was washed with acetic acid $(2 \times 2 \mathrm{~mL})$, isopropyl alcohol $(2 \times 2 \mathrm{~mL})$, and diethyl ether $(2 \times 2 \mathrm{~mL})$, then dried in air. Yield: $104.1 \mathrm{mg}(0.186 \mathrm{mmol}, 82.1 \%)$.

Route c. The reaction was performed using the same experimental set-up as the one described in route a. $\quad$ Potassium pertechnetate $(98.1 \mathrm{mg}, 0.486 \mathrm{mmol})$ was added to the glass vial. The glass vial was placed in a $23 \mathrm{~mL}$ Teflon acid digestion autoclave and $6.00 \mathrm{~mL}$ of glacial acetic acid was dispensed into the glass vial followed by concentrated hydroiodic acid (120 $\mu \mathrm{L}$, $0.908 \mathrm{mmol}$ ) for a molar ratio of 1:2 technetium:iodide. To the Teflon autoclave, outside the glass vial, sodium borohydride $(324 \mathrm{mg}, 8.56 \mathrm{mmol})$ and $0.200 \mathrm{~mL}$ of deionized water was added. The system was sealed and placed in an oven at $210^{\circ} \mathrm{C}$ for 3 days. After 3 days, the autoclave was allowed to cool to room temperature on an aluminum block, and opened. The mother liquor was removed by glass pipet, the brown product $\left(\mathrm{Tc}_{2}\left(\mathrm{O}_{2} \mathrm{CCH}_{3}\right)_{4} \mathrm{I}\right)$ was washed with acetic acid ( $2 \times 2 \mathrm{~mL})$, isopropyl alcohol $(2 \times 2 \mathrm{~mL})$, and diethyl ether $(2 \times 2 \mathrm{~mL})$, then dried in air. Yield: $125.2 \mathrm{mg}(0.223 \mathrm{mmol}, 92 \%)$. 


\subsection{Preparation of $K\left[T c_{8}(\mu-I)_{8} I_{4}\right] I$}

The reaction was performed using the same experimental set-up as the one described above (Figure 1). Potassium pertechnetate $(101.3 \mathrm{mg}, 0.501 \mathrm{mmol})$ and potassium iodide $(84.3$ $\mathrm{mg}, 0.508 \mathrm{mmol}$ ) were added to the glass vial. The glass vial was placed in a $23 \mathrm{~mL}$ Teflon acid digestion autoclave and glacial acetic acid $(6 \mathrm{~mL})$ was added into the glass vial followed by concentrated hydroiodic acid $(198 \mu \mathrm{L}, 1.50 \mathrm{mmol})$. The Tc:KI:HI molar ratio is $\sim 1: 1: 3$. To the Teflon autoclave, outside the glass vial, sodium borohydride $(319 \mathrm{mg}, 8.43 \mathrm{mmol})$ and $0.200 \mathrm{~mL}$ of deionized water were added. The system was sealed and placed in an oven at $210{ }^{\circ} \mathrm{C}$ for 3 days. After 3 days, the autoclave was allowed to cool to room temperature on an aluminum block and opened. The mother liquor was removed by glass pipet, the product was washed with acetic acid ( $2 \times 2 \mathrm{~mL})$, isopropyl alcohol $(2 \times 2 \mathrm{~mL})$, and diethyl ether $(2 \times 2 \mathrm{~mL})$, then dried in air, revealing two crystalline solids: $\mathrm{Tc}_{2}\left(\mathrm{O}_{2} \mathrm{CCH}_{3}\right)_{4} \mathrm{I}$ and $\mathrm{K}\left[\mathrm{Tc}_{8}(\mu-\mathrm{I})_{8} \mathrm{I}_{4}\right] \mathrm{I}$ (144.1 mg total mass). An approximate 2:1 mixture of $\operatorname{Tc}_{2}\left(\mu-\mathrm{O}_{2} \mathrm{CCH}_{3}\right)_{4} \mathrm{I}$ and $\mathrm{K}\left[\mathrm{Tc}_{8}(\mu-\mathrm{I})_{8} \mathrm{I}_{4}\right] \mathrm{I}$ was estimated visually. The dark purple-black, elongated rectangular $\mathrm{K}\left[\mathrm{Tc}_{8}(\mu-\mathrm{I})_{8} \mathrm{I}_{4}\right] \mathrm{I}$ crystals are readily distinguishable to the naked eye from the light brown $\mathrm{Tc}_{2}\left(\mathrm{O}_{2} \mathrm{CCH}_{3}\right)_{4} \mathrm{I}$ crystals and were mechanically separated under a microscope. 


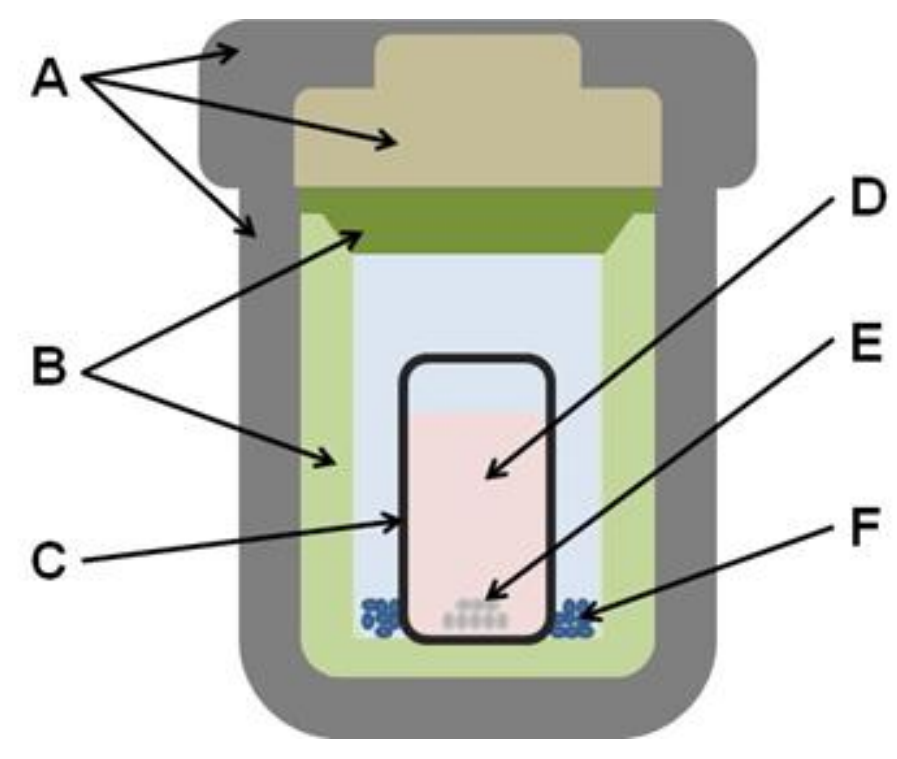

Figure 1. Parr Instrument 4749 autoclave: (A) stainless steel screw cap, body, pressure plates, and rupture discs, (B) $23 \mathrm{~mL}$ Teflon liner, (C) $9 \mathrm{~mL}$ glass vial (1.8 cm I.D. x $3.5 \mathrm{~cm} \mathrm{H})$, (D) liquid reagents, (E) $\mathrm{KTcO}_{4}$, (F) $\mathrm{NaBH}_{4}$ solid.

\subsection{Analysis}

\subsubsection{Single Crystal X-ray Diffraction}

Light brown crystals of $\mathrm{Tc}_{2}\left(\mathrm{O}_{2} \mathrm{CCH}_{3}\right)_{4} \mathrm{I}$ and dark purple rectangular crystals of $\mathrm{K}\left[\mathrm{Tc}_{8}(\mu-\right.$ $\left.\mathrm{I}_{8} \mathrm{I}_{4}\right] \mathrm{I}$ were obtained directly from the washed precipitate and mounted under Paratone on a Kaptan cryoloop for data collection. Single crystal X-ray diffraction data were collected on a Bruker Apex II CCD diffractometer using Mo-K $\mathrm{K}_{\alpha}$ radiation $(\lambda=0.71073 \AA)$. The crystals were maintained at $100 \mathrm{~K}$ during data collection using an Oxford nitrogen cryostream system. The Apex II suite was used to perform data processing and an absorption correction performed with SADABS. Solution to the structure was performed by Direct Methods and refinement was carried out using SHELX ${ }^{[17]}$ and OLEX2. ${ }^{[18]}$

For $\mathrm{Tc}_{2}\left(\mu-\mathrm{O}_{2} \mathrm{CCH}_{3}\right)_{4} \mathrm{I}$, anisotropic approximations of all atoms except hydrogen were refined against $\mathrm{F}^{2}$, whereas the hydrogen atoms positions were determined geometrically and refined using the riding model. All crystal structure visualizations were prepared in Mercury 3.3 
software. ${ }^{[19]}$ Crystallographic data and refinement parameters for $\mathrm{Tc}_{2}\left(\mu-\mathrm{O}_{2} \mathrm{CCH}_{3}\right)_{4} \mathrm{I}$ are shown in Table S1 and accounting for hydrogens the final R-factor $=0.0167$.

For $\mathrm{K}\left[\mathrm{Tc}_{8}(\mu-\mathrm{I})_{8} \mathrm{I}_{4}\right] \mathrm{I}$, the resulting data showed the crystal was a non-merohedral twin and refinement against both crystal domains was attempted but produced a substantial high R-value after which refinement against a single merged domain provided an R-value of 0.0277 . Crystallographic data and refinement parameters for compound $\mathrm{K}\left[\mathrm{Tc}_{8}(\mu-\mathrm{I})_{8} \mathrm{I}_{4}\right] \mathrm{I}$ are shown in Table S6. Full details on crystallographic data for the structures of $K\left[\operatorname{Tc}_{8}(\mu-I)_{8} I_{4}\right] I$ and $\operatorname{Tc}_{2}(\mu-$ $\left.\mathrm{O}_{2} \mathrm{CCH}_{3}\right)_{4} \mathrm{I}$ are tabled in the Supporting Information.

\subsubsection{Elemental}

For ${ }^{99} \mathrm{Tc}$ elemental analyses, weighed amounts of the compounds ( $c a .5 \mathrm{mg}$ ) were suspended in $5 \mathrm{~mL}$ of ammonium hydroxide for several days. After complete dissolution, the solutions were diluted to $10 \mathrm{~mL}$ with DI $\mathrm{H}_{2} \mathrm{O}$. Samples for LSC were prepared by mixing 100 $\mu \mathrm{L}$ of sample solution containing ${ }^{99} \mathrm{Tc}$ and $100 \mu \mathrm{L}$ of $\mathrm{DI} \mathrm{H}_{2} \mathrm{O}$, to correspond to calibration

curves, with $10 \mathrm{~mL}$ of scintillation cocktail. ${ }^{99} \mathrm{Tc}$ concentrations were determined by liquid scintillation counting using a Perkin Elmer liquid scintillation counter Tri-Carb 3100TR. The scintillation cocktail was ULTIMA GOLD ABTM (Packard). US-EPA Method 345.1 was used to determine the amount of iodide. ${ }^{[20]}$

\subsubsection{Magnetic measurements}

Magnetic susceptibility measurements were performed on $\mathrm{Tc}_{2}\left(\mathrm{O}_{2} \mathrm{CCH}_{3}\right)_{4} \mathrm{I}$ in a $0.1 \mathrm{~T}$ applied field from 10 to $300 \mathrm{~K}$ using a Quantum Design PPMS. The sample (83.3 mg, 0.146 mmol) was placed in a medical gel-capsule packed with cotton. The capsule was wrapped, sealed with Parafilm and inserted securely into the bottom of a plastic straw fitted onto the PPMS sample holder. Infrared spectra were measured in an attenuated total reflectance (ATR) module with germanium objective using a Varian 3100 FT-IR Excalibur spectrometer. 


\section{Results and Discussion}

\subsection{Preparation of $\mathrm{Tc}_{2}\left(\mathrm{O}_{2} \mathrm{CCH}_{3}\right)_{4} I$ and $\mathrm{K}\left[T c_{8}(\mu-I)_{8} I_{4}\right] I$.}

Historically, $\mathrm{Tc}_{2}\left(\mathrm{O}_{2} \mathrm{CCH}_{3}\right)_{4} \mathrm{Cl}_{2}$ was the first dinuclear technetium complex coordinated to acetate ligands to be reported. ${ }^{[14-15]}$ This compound was synthesized by treating potassium pertechnetate $\left(\mathrm{KTcO}_{4}\right)$ in an acetic acid/ $\mathrm{HCl}$ mixture at $210{ }^{\circ} \mathrm{C}$ in large stainless steel autoclaves that were pressurized to $30 \mathrm{~atm}$ with hydrogen gas. In these earlier preparations, the autoclaves corroded rapidly upon exposure to the hot concentrated mineral acid. In our syntheses, Tefloncoated vessels were used and hydrogen was generated in-situ from the reaction of solid sodium borohydride with $\mathrm{H}_{2} \mathrm{O} / \mathrm{HX}$ vapors (Figure 1) during the course of the reaction. The reaction of $\mathrm{KTcO}_{4}$, with iodide salts and/or hydroiodic acid in glacial acetic acid at $210{ }^{\circ} \mathrm{C}$ under $60-70$ atm hydrogen afforded $\mathrm{Tc}_{2}\left(\mathrm{O}_{2} \mathrm{CCH}_{3}\right)_{4} \mathrm{I}$ and $\mathrm{K}\left[\mathrm{Tc}_{8}(\mu-\mathrm{I})_{8} \mathrm{I}_{4}\right] \mathrm{I}$. Under our experimental conditions, the paddlewheel technetium(III, III) dimer, $\mathrm{Tc}_{2}\left(\mathrm{O}_{2} \mathrm{CCH}_{3}\right)_{4} \mathrm{I}_{2}$, was not observed. Experiments performed in acetic acid with a Tc:MI molar ratio of 1:2 $(\mathrm{M}=\mathrm{K}, \mathrm{Na}, \mathrm{H})$ provided exclusively $\mathrm{Tc}_{2}\left(\mathrm{O}_{2} \mathrm{CCH}_{3}\right)_{4} \mathrm{I}$ in a ca. $~ 80-90 \%$ yield. Experiments performed with a Tc:MI:HI molar ratio of 1:1:3 provided a mixture of $\mathrm{K}\left[\mathrm{Tc}_{8}(\mu-\mathrm{I})_{8} \mathrm{I}_{4}\right] \mathrm{I}$ and $\mathrm{Tc}_{2}\left(\mathrm{O}_{2} \mathrm{CCH}_{3}\right)_{4} \mathrm{I}$. An approximate ratio of $\mathrm{Tc}_{2}\left(\mathrm{O}_{2} \mathrm{CCH}_{3}\right)_{4} \mathrm{I}: \mathrm{K}\left[\mathrm{Tc}_{8}\left(\mu-\mathrm{I}_{8} \mathrm{I}_{4}\right] \mathrm{I}\right.$ of $\sim 2: 1$ was visually estimated. Crystals of the individual compounds were hand separated under a microscope; $\mathrm{Tc}_{2}\left(\mathrm{O}_{2} \mathrm{CCH}_{3}\right)_{4} \mathrm{I}$ is light brown and $\mathrm{K}\left[\mathrm{Tc}_{8}(\mu-\mathrm{I})_{8} \mathrm{I}_{4}\right] \mathrm{I}$ is purple.

The halogen analogues of $\mathrm{Tc}_{2}\left(\mathrm{O}_{2} \mathrm{CCH}_{3}\right)_{4} \mathrm{I}$, i.e., $\mathrm{Tc}_{2}\left(\mathrm{O}_{2} \mathrm{CCH}_{3}\right)_{4} \mathrm{Cl}^{[21]}$ and $\mathrm{Tc}_{2}\left(\mathrm{O}_{2} \mathrm{CCH}_{3}\right)_{4} \mathrm{Br},{ }^{[22]}$ were respectively synthesized in autoclaves after treatment of $\mathrm{K}_{3} \mathrm{Tc}_{2} \mathrm{Cl}_{8} \cdot 2 \mathrm{H}_{2} \mathrm{O}$ in glacial acetic acid at $120{ }^{\circ} \mathrm{C}$ under $30 \mathrm{~atm}$ of argon or hydrogen, and after treatment of $\mathrm{K}_{2} \mathrm{Tc}_{2} \mathrm{Br}_{6} \cdot 2 \mathrm{H}_{2} \mathrm{O}$ in acetic acid at $230{ }^{\circ} \mathrm{C}$ under argon. The octanuclear technetium bromide clusters $\left(\left[\mathrm{H}\left(\mathrm{H}_{2} \mathrm{O}\right)_{2}\right]_{2}\left\{\left[\mathrm{Tc}_{8}\left(\left(\mu-\mathrm{Br}_{8} \mathrm{Br}_{4}\right] \mathrm{Br}_{2}\right\}, \quad\left[\mathrm{H}\left(\mathrm{H}_{2} \mathrm{O}\right)_{2}\right]\left\{\left[\mathrm{Tc}_{8}\left((\mu-\mathrm{Br})_{8} \mathrm{Br}_{4}\right] \mathrm{Br}\right\}\right.\right.\right.\right.$, and $\left.\left\{\left[\mathrm{Tc}_{8}(\mu-\mathrm{Br})_{8} \mathrm{Br} 4\right] \mathrm{Br}\right\} \cdot 2 \mathrm{H}_{2} \mathrm{O}\right)$ were synthesized from the reaction of $\mathrm{HTcO}_{4}$ or $\mathrm{H}_{2} \mathrm{TcBr}_{6}$ with hydrobromic acid in autoclaves (30-50 atm hydrogen) in the temperature range $130-200{ }^{\circ} \mathrm{C} .{ }^{[23]}$ Previous attempts to synthesize iodide clusters from the hydrothermal reaction of $\mathrm{HTcO}_{4}$ in $\mathrm{HI}$ at $140-220{ }^{\circ} \mathrm{C}$ under hydrogen were unsuccessful. Those reactions produced a small amount of black powder that was only characterized through elemental analysis as $\mathrm{TcI}_{2} \cdot 0.5 \mathrm{H}_{2} \mathrm{O}{ }^{[24]}$ In our reaction, the preferential formation of $\mathrm{K}\left[\mathrm{Tc}_{8}(\mu-\mathrm{I})_{8} \mathrm{I}_{4}\right] \mathrm{I}$ over a divalent iodide hydrate might be due 
to the presence of glacial acetic acid as a solvent which minimizes hydrolysis of the reaction products. The formation mechanism(s) of polynuclear technetium halide clusters under hydrothermal conditions are not well understood. It was previously postulated that the hexaand octanuclear bromide and chloride clusters were formed from the cycloaddition of $\mathrm{Tc}_{2} \mathrm{X}_{8}{ }^{\mathrm{n}-}(\mathrm{n}$ $=4,5 ; \mathrm{X}=\mathrm{Cl}, \mathrm{Br}$ ) anions, but no experimental evidence has been provided.

\subsection{Structure and magnetic properties of $\left[\mathrm{Tc}_{2}\left(\mu-\mathrm{O}_{2} \mathrm{CCH}_{3}\right)_{4}\right] \mathrm{I}$.}

The compound $\mathrm{Tc}_{2}\left(\mathrm{O}_{2} \mathrm{CCH}_{3}\right)_{4} \mathrm{I}$ crystallizes in the monoclinic space group $\mathrm{C} 2 / \mathrm{m}$ (Table $\mathrm{S} 1)$. The structure of $\mathrm{Tc}_{2}\left(\mathrm{O}_{2} \mathrm{CCH}_{3}\right)_{4} \mathrm{I}$ consists of infinite chains of $\left[\mathrm{Tc}_{2}\left(\mathrm{O}_{2} \mathrm{CCH}_{3}\right)_{4}\right]^{+}$units linked by bridging iodide ligand (Figure 2). The structure of $\mathrm{Tc}_{2}\left(\mathrm{O}_{2} \mathrm{CCH}_{3}\right)_{4} \mathrm{I}$ is similar to that of $\mathrm{Tc}_{2}\left(\mathrm{O}_{2} \mathrm{CCH}_{3}\right)_{4} \mathrm{Br}$, but differs slightly from that of $\mathrm{Tc}_{2}\left(\mathrm{O}_{2} \mathrm{CCH}_{3}\right)_{4} \mathrm{Cl}$. In $\mathrm{Tc}_{2}\left(\mathrm{O}_{2} \mathrm{CCH}_{3}\right)_{4} \mathrm{Cl}$, the TcTc-X angle is $120^{\circ}$, resulting in a zig-zag chain, while a value of $180^{\circ}$ is observed in $\mathrm{Tc}_{2}\left(\mathrm{O}_{2} \mathrm{CCH}_{3}\right)_{4} \mathrm{X}(\mathrm{X}=\mathrm{Br}, \mathrm{I})$ (Table 1). The compound $\mathrm{Tc}_{2}\left(\mathrm{O}_{2} \mathrm{CCH}_{3}\right)_{4} \mathrm{I}$ packs as parallel chains along the $a$-axis with the $b$ - and $c$-axes exhibiting staggered parallel chains within the unit cell, a similar arrangement is observed in $\mathrm{Tc}_{2}\left(\mathrm{O}_{2} \mathrm{CCH}_{3}\right)_{4} \mathrm{Br}$ (Figure 3). Extended metal atom chains (EMACs) containing carboxylate bridged metal dimers are also known for ruthenium and rhenium. For ruthenium, more than 20 compounds containing the $\mathrm{Ru}_{2}^{5+}$ core have been reported; ${ }^{[25]}$ these include $\mathrm{Ru}_{2}\left(\mathrm{O}_{2} \mathrm{CCH}_{3}\right)_{4} \mathrm{Cl}^{[26]}$ and $\mathrm{Ru}_{2}\left(\mathrm{O}_{2} \mathrm{CH}\right)_{4} \mathrm{Br}^{[27]}$ Surprisingly, EMAC compounds that contain the $\mathrm{Re}_{2}{ }^{5+}$ core coordinated to carboxylate ligands have been not reported. This is an example of where technetium chemistry follows ruthenium rather than rhenium. We note that several EMACs with $\mathrm{Re}_{2}{ }^{6+}$ tricarboxylate cores bridged by chloride ligands have been reported, ${ }^{[28]}$ including $\mathrm{Re}_{2}\left(\mathrm{O}_{2} \mathrm{CCMe}_{3}\right)_{3} \mathrm{Cl}_{3}$. In the latter compound, the $\mathrm{Re}-\mathrm{Re}$ separation is 2.229(3) $\AA$ and the Re-Cl-Re angle is $134^{\circ}$. [29]

In $\mathrm{Tc}_{2}\left(\mathrm{O}_{2} \mathrm{CCH}_{3}\right)_{4} \mathrm{I}$, the Tc-Tc separation of 2.1146(4) $\AA$ is slightly longer than the one found in $\mathrm{Tc}_{2}\left(\mathrm{O}_{2} \mathrm{CCH}_{3}\right)_{4} \mathrm{Br}(2.112(1) \AA)$ and slightly shorter than the one in $\mathrm{Tc}_{2}\left(\mathrm{O}_{2} \mathrm{CCH}_{3}\right)_{4} \mathrm{Cl}$ (2.117(1) $\AA$ ) (Table 1). The Tc-Tc separations in $\mathrm{Tc}_{2}\left(\mathrm{O}_{2} \mathrm{CCH}_{3}\right)_{4} \mathrm{X}(\mathrm{X}=\mathrm{Cl}, \mathrm{Br}, \mathrm{I})$ are consistent with the presence of the $\mathrm{Tc}_{2}{ }^{5+}$ core (electronic configuration $\sigma^{2} \pi^{4} \delta^{2} \delta^{* 1}$ ). ${ }^{[3]}$ The Tc-Tc separations in $\mathrm{Tc}_{2}\left(\mathrm{O}_{2} \mathrm{CCH}_{3}\right)_{4} \mathrm{X}\left(\mathrm{X}=\mathrm{Cl}, \mathrm{Br}\right.$, I) are shorter than those in $\mathrm{Tc}_{2}\left(\mathrm{O}_{2} \mathrm{CCH}_{3}\right)_{4} \mathrm{Cl}_{2}$ $(2.1785(3) \AA)^{[15]}$ and $\mathrm{Tc}_{2}\left(\mathrm{O}_{2} \mathrm{CCMe}_{3}\right)_{4} \mathrm{Cl}_{2}(2.192(2) \AA) .{ }^{[30]}$ This phenomenon is likely due to stronger metal-metal $\pi$ bonding in the $\mathrm{Tc}_{2}{ }^{5+}$ core than in the $\mathrm{Tc}_{2}{ }^{6+}$ core as was previously 
discussed for the $\mathrm{Tc}_{2} \mathrm{X}_{8}{ }^{\mathrm{n}-}(\mathrm{n}=2,3 ; \mathrm{X}=\mathrm{Cl}, \mathrm{Br})$ systems. ${ }^{[31]}$ It should be noted that the same trend is observed in rhenium metal-metal bonding for $\left[\mathrm{Re}_{2} \mathrm{Cl}_{4}\left(\mathrm{PMe}_{2} \mathrm{Ph}\right)_{4}\right] \mathrm{PF}_{6}, \mathrm{Re}_{2}{ }^{+5}$ core (electronic configuration $\sigma^{2} \pi^{4} \delta^{2} \delta^{* 1}$ ) and $\mathrm{Re}_{2} \mathrm{Cl}_{6}\left(\mathrm{PEt}_{3}\right)_{2}, \mathrm{Re}_{2}{ }^{+6}$ core (electronic configuration $\sigma^{2} \pi^{4} \delta^{2}$ ) compounds described by Cotton, et al., concluding an increase in Re-Re bond length based on increase from 3.5 to 4 bond order. ${ }^{32}$

Magnetic susceptibility measurements were performed in temperature range from 4-300 $\mathrm{K}$. The data (Figure S2) indicates the compound to be paramagnetic, which is consistent with the presence of a single unpaired electron in the $\mathrm{Tc}_{2}{ }^{5+}$ core (i.e., $\sigma^{2} \pi^{4} \delta^{2} \delta^{* 1}$ ). The magnetic moment for $\mathrm{Tc}_{2}\left(\mathrm{O}_{2} \mathrm{CCH}_{3}\right)_{4} \mathrm{I}\left(\mu_{\text {eff }}=1.84\right.$ B.M.) is comparable to the ones reported previously for $\mathrm{Tc}_{2}\left(\mathrm{O}_{2} \mathrm{CCH}_{3}\right)_{4} \mathrm{Cl}$ and $\mathrm{Tc}_{2}\left(\mathrm{O}_{2} \mathrm{CCH}_{3}\right)_{4} \mathrm{Br}$, i.e., 1.73 and $\sim 2.0 \mathrm{~B} . \mathrm{M}$, respectively. ${ }^{[33]}$

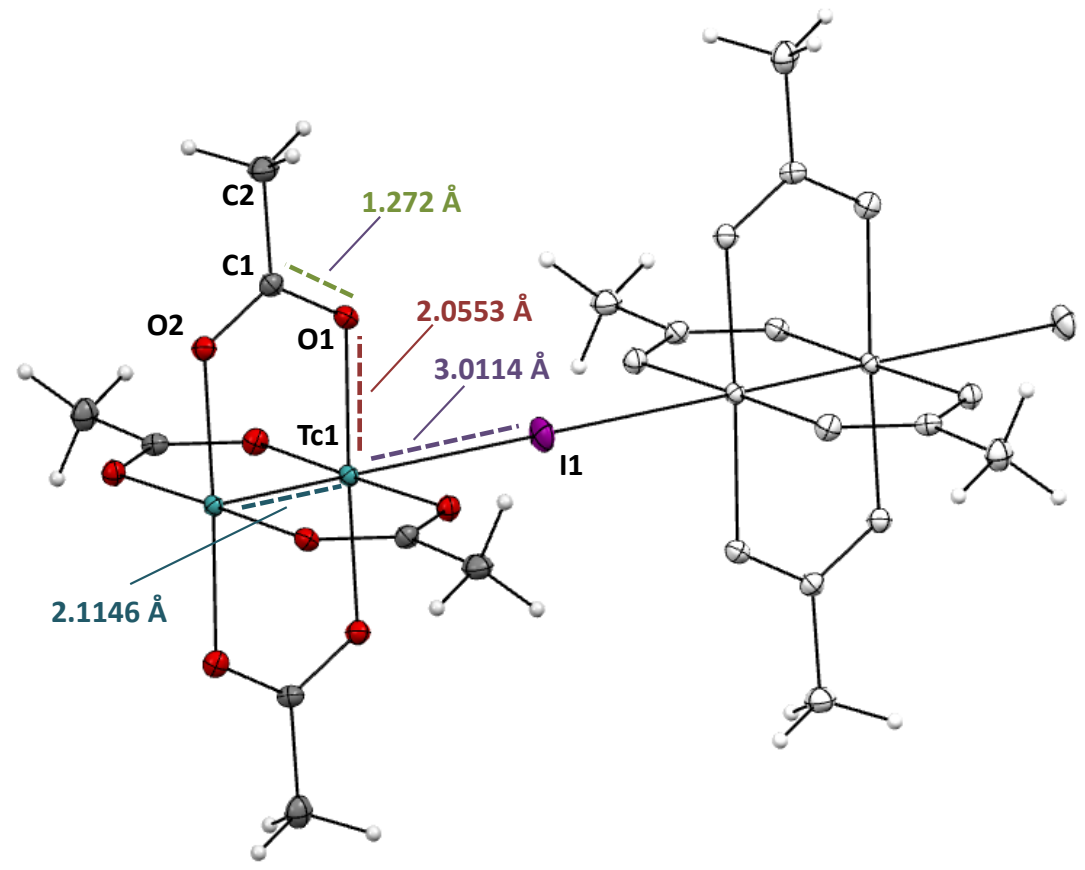

Figure 2. Ball and stick representation of $\mathrm{Tc}_{2}\left(\mathrm{O}_{2} \mathrm{CCH}_{3}\right)_{4} \mathrm{I}$. Ellipsoids are shown at the $50 \%$ probability level with selected bond lengths in $\AA$. Color of atoms: Tc in turquoise, I in purple, C in gray, $\mathrm{O}$ in red and $\mathrm{H}$ in white. 

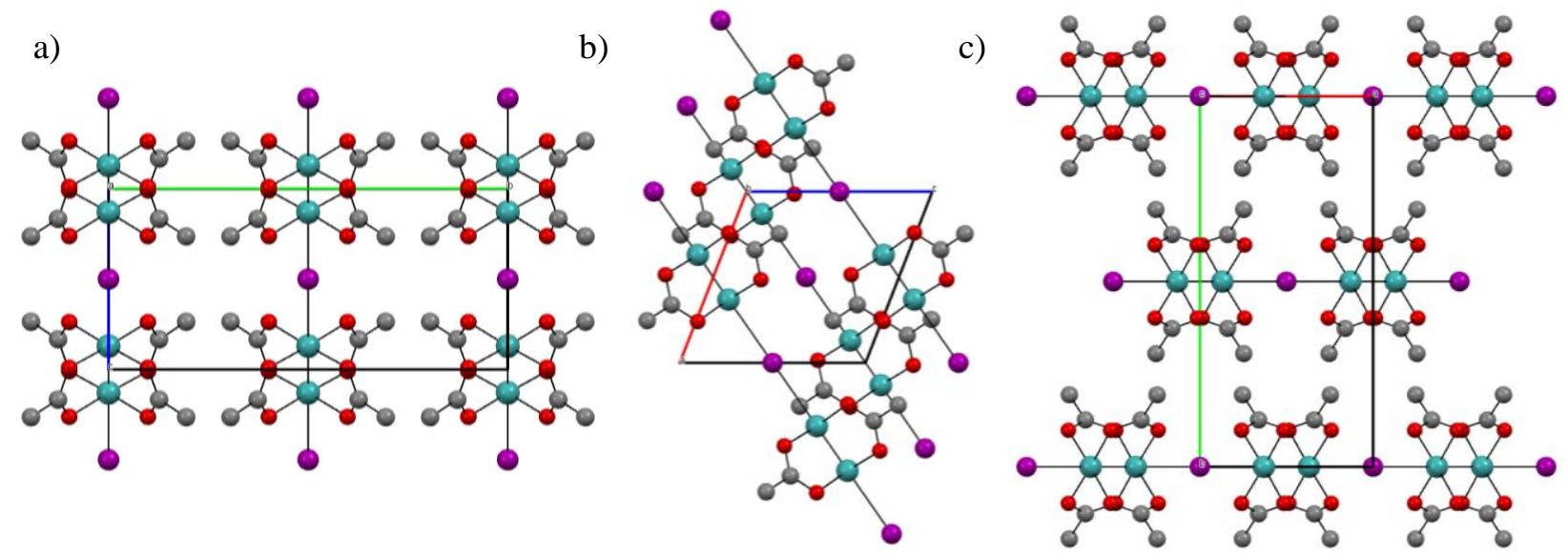

Figure 3. Unit cell packing for $\mathrm{Tc}_{2}\left(\mathrm{O}_{2} \mathrm{CCH}_{3}\right)_{4} \mathrm{I}$ along the a) $a$-axis, b) $b$-axis and c) $c$-axis. Color of atoms: Tc in turquoise, $\mathrm{I}$ in purple, $\mathrm{C}$ in gray, $\mathrm{O}$ in red and $\mathrm{H}$ omitted for clarity.

Table 1. Selected interatomic distances $(\AA)$ and angles $\left(^{\circ}\right)$ for compounds with $\mathrm{Tc}_{2}{ }^{5+}$ and $\mathrm{Tc}_{2}{ }^{6+}$ cores coordinated to carboxylate and halogen ligands.

\begin{tabular}{|l|l|l|l|l|l|l|}
\hline Compound & Tc-Tc & Tc-O & Tc-X & Tc-Tc-X & Tc-X-Tc & {$[$ Ref $]$} \\
\hline $\mathrm{Tc}_{2}\left(\mathrm{O}_{2} \mathrm{CCH}_{3}\right)_{4} \mathrm{Cl}$ & $2.117(1)$ & $2.065[5]$ & $2.656(1)$ & $176.07(6)$ & $119.32(6)$ & {$[12]$} \\
\hline $\mathrm{Tc}_{2}\left(\mathrm{O}_{2} \mathrm{CCH}_{3}\right)_{4} \mathrm{Br}$ & $2.112(1)$ & $2.060[4]$ & $2.843(1)$ & $179.63(3)$ & 180.0 & {$[13]$} \\
\hline $\mathrm{Tc}_{2}\left(\mathrm{O}_{2} \mathrm{CCH}_{3}\right)_{4} \mathrm{I}$ & $2.1146(4)$ & $2.0553[13]$ & $3.0114(3)$ & $179.534(14)$ & 180.00 & this work \\
\hline $\mathrm{Tc}_{2}\left(\mathrm{O}_{2} \mathrm{CCH}_{3}\right)_{4} \mathrm{Cl}_{2}$ & $2.1758(3)$ & $2.0211[12]$ & $2.5078(4)$ & $171.903(13)$ & - & {$[15]$} \\
\hline $\mathrm{Tc}_{2}\left(\mathrm{O}_{2} \mathrm{CCMe}_{3}\right)_{4} \mathrm{Cl}_{2}$ & $2.192(2)$ & $2.032[4]$ & $2.408(4)$ & 180.00 & - & {$[30]$} \\
\hline
\end{tabular}

\subsection{Structure of $K\left[T c_{8}(\mu-I)_{8} I_{4}\right] I$}

The compound $\mathrm{K}\left[\mathrm{Tc}_{8}(\mu-\mathrm{I})_{8} \mathrm{I}_{4}\right] \mathrm{I}$ crystallizes in the monoclinic space group P2(1)/n (Table S6). The compound contains the tetragonal-prismatic $\left[\mathrm{Tc}_{8}(\mu-\mathrm{I})_{8} \mathrm{I}_{4}\right]$ cluster (Figure 4) and is the first octanuclear technetium cluster coordinated solely to iodide ligands to be reported. In the $\left[\operatorname{Tc}_{8}\left(\mu-I_{8} \mathrm{I}_{4}\right]\right.$ cluster, there are nominally four $\operatorname{Tc}(+2)$ atoms and four $\mathrm{Tc}(+1)$ atoms $(44$ cluster 
electrons). Three distinct metal-metal separations are observed: four short Tc-Tc bonds (2.164(3) $\AA$ ) along the edges of the tetragonal pyramid, two Tc-Tc bonds forming the short diagonals of the prism faces $(2.5308(8) \AA$ ), and eight longer Tc-Tc longer bonds (2.72(3) $\AA$ ) forming the bases of the prism. The shortest metal-metal separation (2.164(3) $\AA$ ) is characteristic of electron-rich $\mathrm{Tc} \equiv \mathrm{Tc}$ triple bonds, while the longest $(2.72(3) \AA)$ is characteristic of Tc-Tc single bonds. The Tc-Tc separations of 2.5308(8) $\AA$ suggest the presence of Tc=Tc double bonds (or at least Tc-Tc bonds with some degree of multiple bond character). ${ }^{[34]}$ The overall geometry of the $\left[\mathrm{Tc}_{8}\left(\mu-\mathrm{I}_{8} \mathrm{I}_{4}\right]\right.$ cluster is similar to the ones found in the $\left[\mathrm{Tc}_{8}\left(\mu-\mathrm{Br}_{8}\right)_{8} \mathrm{Br}_{4}\right]^{\mathrm{n}}(\mathrm{n}$ $=0,1)$ clusters. We are aware of only one paper probing the metal-metal bonding in an octanuclear technetium cluster of the type described here. ${ }^{35}$ Unfortunately, few details were provided. It would seem that $\left[\mathrm{Tc}_{8}(\mu-\mathrm{X})_{8} \mathrm{X}_{4}\right]$ clusters $(\mathrm{X}=\mathrm{Br}, \mathrm{I})$ are prime targets for additional theoretical investigations. Selected interatomic bond distances for hexa-and octanuclear technetium bromide and iodide clusters are shown in Table 2. The shortest Tc-Tc separations in the isoelectronic $\left[\mathrm{Tc}_{8}\left(\mu-\mathrm{Br}_{8} \mathrm{Br}_{4}\right]\right.$ cluster (i.e., 2.155(3) $\AA$ and 2.152(9) $\AA$ ) are slightly shorter than the ones found in $\left[\operatorname{Tc}_{8}(\mu-\mathrm{I})_{8} \mathrm{I}_{4}\right]$. In the trigonal-prismatic $\left[\mathrm{Tc}_{6}\left(\mu-\mathrm{I}_{6} \mathrm{I}_{6}\right]^{1-}\right.$ cluster, ${ }^{[36]}$ the shortest Tc-Tc separation $(2.18(1) \AA)$ is slightly longer than the one in $\left[\mathrm{Tc}_{8}\left(\mu-\mathrm{I}_{8} \mathrm{I}_{4}\right]\right.$. The $\left[\mathrm{Tc}_{8}(\mu-\right.$ $\left.\mathrm{I}_{8} \mathrm{I}_{4}\right]$ cluster contains eight bridging $\left(\mathrm{Tc}-\mathrm{I}_{\mathrm{bri}}=2.68[3] \AA\right)$ and four terminal $\left(\mathrm{Tc}-\mathrm{I}_{\mathrm{term}}=2.731[12]\right.$ $\AA$ ) iodide ligands. The $\left[\mathrm{Tc}_{8}\left(\mu-\mathrm{I}_{8} \mathrm{I}_{4}\right]\right.$ cluster is also capped by one iodine atom, with the shortest Tc- $\mathrm{I}_{\text {cap }}$ distance being $3.187(53) \AA$. The packing of the $\left[\mathrm{Tc}_{8}\left(\mu-\mathrm{I}_{8} \mathrm{I}_{4}\right]\right.$ cluster within the unit cell (Figure 5) along the $a$-axis and $b$-axis shows the rhombohedral face of the top half of the cluster. The shortest I $\cdots$ I separation between clusters is 3.7455(2) $\AA$ through terminal-equatorial iodide contacts, or somewhat less than the sum of the Van der Waals radii $(\sim 4.2 \AA)$. ${ }^{[37]}$ 


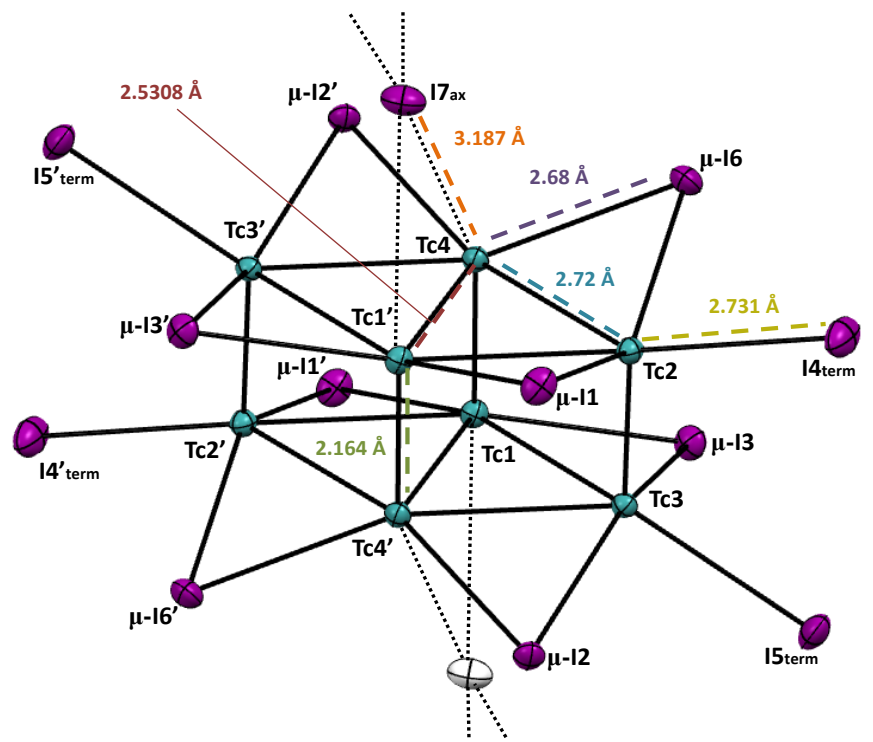

Figure 4. Ball and stick representation of $\mathrm{K}\left[\mathrm{Tc}_{8}(\mu-\mathrm{I})_{8} \mathrm{I}_{4}\right] \mathrm{I}$. Ellipsoids are shown at the $70 \%$ probability level with selected bond lengths $(\AA)$. Color of atoms: Tc in turquoise, $\mathrm{K}$ in white and I in purple.

Table 2. Selected Interatomic bond distances $(\AA)$ in hexa- and octanuclear technetium clusters

\begin{tabular}{|l|l|l|l|l|c|}
\hline Compound & Tc-Tc & Tc- $\mathrm{X}_{\text {term }}$ & Tc- $\mathrm{Bri}_{\text {Bri }}$ & Tc- $\mathrm{X}_{\text {cap }}$ & {$[$ Ref $]$} \\
\hline $\mathrm{K}\left[\mathrm{Tc}_{8}(\mu-\mathrm{I})_{8} \mathrm{I}_{4}\right] \mathrm{I}$ & $\begin{array}{l}2.164 / 3 /, 2.5308(8), \\
2.72 / 3 /\end{array}$ & $2.731 / 12 /$ & $2.68 / 3 /$ & $3.187 / 53 /$ & this work \\
\hline$\left.\left[\mathrm{FeCp}_{2}\right]_{3}\left\{\mathrm{Tc}_{6}(\mu-\mathrm{I})_{6} \mathrm{I}_{6}\right] \mathrm{I}_{2}\right\}$ & $2.18(1), 2.67(1)$ & $2.71(1)$ & $2.61 / 2 /$ & $3.26(2)$ & {$[36]$} \\
\hline$\left[\mathrm{H}\left(\mathrm{H}_{2} \mathrm{O}\right)_{2}\right]\left\{\left[\mathrm{Tc}_{8}(\mu-\mathrm{Br})_{8} \mathrm{Br}_{4}\right] \mathrm{Br}\right\}$ & $2.155 / 3 /, 2.531 / 2 /$ & $2.53 / 2 /$ & $2.51 / 2 /$ & $2.99 / 7 /$ & {$[38,39]$} \\
& $2.70 / 2 /$ & & & & \\
\hline$\left[\mathrm{H}\left(\mathrm{H}_{2} \mathrm{O}\right)_{2}\right]_{2}\left\{\left[\mathrm{Tc}_{8}(\mu-\mathrm{Br})_{8} \mathrm{Br}_{4}\right] \mathrm{Br}_{2}\right\}$ & $\begin{array}{l}2.152 / 9 /, 2.520 / 9 / \\
2.69(1)\end{array}$ & $2.52 / 1 /$ & $2.52 / 1 /$ & $2.90 / 2 /$ & {$[39,40]$} \\
\hline$\left[\mathrm{Tc}_{8}(\mu-\mathrm{Br})_{8} \mathrm{Br}_{4}\right] \mathrm{Br} \cdot 2 \mathrm{H}_{2} \mathrm{O}$ & $2.146(2), 2.521(2)$ & $2.509 / 8 /$ & $2.50 / 2 /$ & $3.00 / 7 /$ & {$[41]$} \\
& $2.69 / 2 /$ & & & & \\
\hline
\end{tabular}

Standard errors are given in rounded brackets and deviations from mean values- $/ \mathrm{x} /$. 

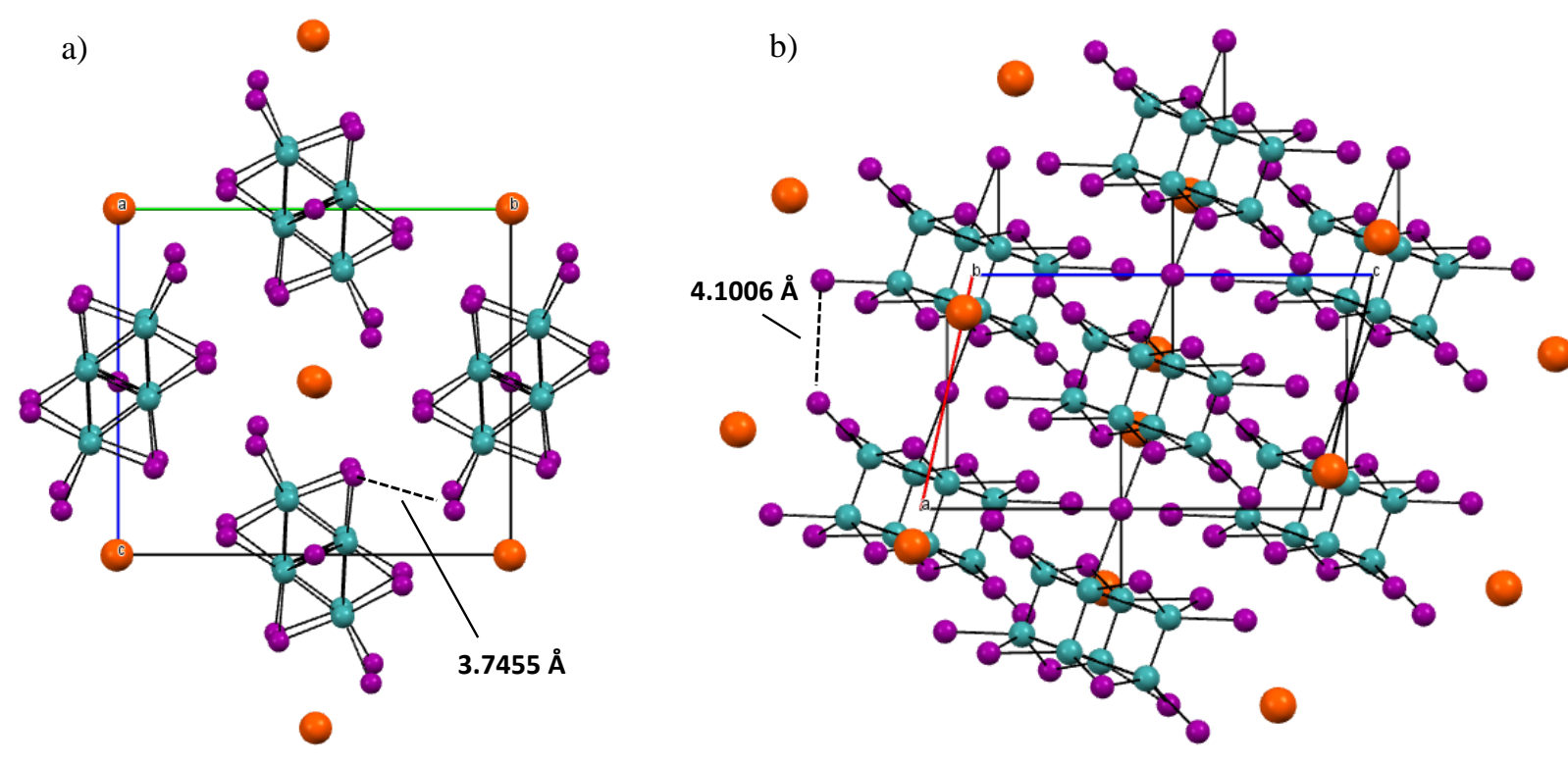

Figure 5. Unit cell packing along the (a) $a$-axis and (b) $b$-axis. Color of atoms: Tc in turquoise, I in purple and $\mathrm{K}$ in orange. The iodine-iodine Van der Waals distances for terminal-equatorial (a) and terminal-terminal (b) are shown.

\section{Conclusion}

In summary, two new technetium metal-metal bonded iodide compounds, $\mathrm{Tc}_{2}\left(\mathrm{O}_{2} \mathrm{CCH}_{3}\right)_{4} \mathrm{I}$ and $\mathrm{K}\left[\mathrm{Tc}_{8}\left(\mu-\mathrm{I}_{8} \mathrm{I}_{4}\right] \mathrm{I}\right.$, were synthesized via the hydrothermal reduction of $\mathrm{KTcO}_{4}$ in acetic acid/MI $(\mathrm{M}=\mathrm{Na}, \mathrm{K}, \mathrm{H})$ media and their $\mathrm{X}$-ray crystal structures elucidated. The discovery of $\mathrm{Tc}_{2}\left(\mathrm{O}_{2} \mathrm{CCH}_{3}\right)_{4} \mathrm{I}$ brings to four the number of structurally characterized complexes with the $\mathrm{Tc}_{2}{ }^{5+}$ unit coordinated to acetate ligands while $\mathrm{K}\left[\mathrm{Tc}_{8}(\mu-\mathrm{I})_{8} \mathrm{I}_{4}\right] \mathrm{I}$ is the first technetium iodide octanuclear cluster to be reported. The Tc-Tc separation in $\mathrm{Tc}_{2}\left(\mathrm{O}_{2} \mathrm{CCH}_{3}\right)_{4} \mathrm{I}$ is consistent with the presence of the $\mathrm{Tc}_{2}{ }^{5+}$ core with the electronic configuration $\sigma^{2} \pi^{4} \delta^{2} \delta^{*}$. The Tc-Tc separations in $\operatorname{K}\left[\mathrm{Tc}_{8}(\mu-\right.$ $\mathrm{I}_{8} \mathrm{I}_{4} \mathrm{I}$ are consistent with the presence of Tc-Tc single bonds, $\mathrm{Tc}=\mathrm{Tc}$ double bonds and $\mathrm{Tc} \equiv \mathrm{Tc}$ triple bonds. Magnetic measurements were performed on $\mathrm{Tc}_{2}\left(\mathrm{O}_{2} \mathrm{CCH}_{3}\right)_{4} \mathrm{I}$. The results show the compound to be paramagnetic, consistent with the electronic configuration $\sigma^{2} \pi^{4} \delta^{2} \delta^{* 1}$. It is expected that $\mathrm{Tc}_{2}\left(\mathrm{O}_{2} \mathrm{CCH}_{3}\right)_{4} \mathrm{I}$ will serve as a precursor for the synthesis of other multiply metalmetal bonded complexes, e.g., $\mathrm{Tc}_{2} \mathrm{I}_{8}{ }^{2-}$ or $\mathrm{Tc}_{2}\left(\mathrm{O}_{2} \mathrm{CCH}_{3}\right)_{4} \mathrm{I}_{2}$. Other routes to $\mathrm{M}\left[\mathrm{Tc}_{8}\left(\mu-\mathrm{I}_{8} \mathrm{I}_{4}\right] \mathrm{I}\right.$ are being explored. 


\section{Acknowledgments}

Funding for this research was provided by a SISGR Grant from the U.S. Department of Energy, Office of Science, Office of Basic Energy Sciences, under Contract No. 47824B. The authors thank Mr. Trevor Low and Ms. Julie Bertoia for outstanding health physics support. The authors also acknowledge the assistance of Professor Andrew L. Cornelius and Daniel Antonio (UNLV Physics and Astronomy Department) with the magnetic susceptibility measurements.

We would also like to thank the guest editors Professor Larry R. Falvello (Zaragoza) and Professor Carlos A. Murillo (Texas A\&M) for the opportunity to publish in this special issue of Inorganica Chimica Acta commemorating the $50^{\text {th }}$ anniversary of the publications by F.A. Cotton and coworkers detailing the synthesis, x-ray structure, and metal-metal bonding in $\mathrm{Re}_{2} \mathrm{Cl}_{8}{ }^{2-}$.

\section{Appendix A. Supplementary Information}

Single crystal X-ray diffraction data for $\mathrm{Tc}_{2}\left(\mathrm{O}_{2} \mathrm{CCH}_{3}\right)_{4} \mathrm{I}$ has been deposited with the Cambridge Crystallographic Data Centre, CCDC No. 995651. Copies of this information may be obtained free of charge from the Director, CCDC, 12 Union Road, Cambridge, CB2 1EZ, UK (fax: +44 1223 336033; email: deposit@ccdc.cam.ac.uk or www.ccdc.cam.ac.uk). Single crystal X-ray diffraction data for $\mathrm{K}\left[\mathrm{Tc}_{8}(\mu-\mathrm{I})_{8} \mathrm{I}_{4}\right] \mathrm{I}$ has been deposited in Fachinformationszentrum Karlsruhe (FIZ) 76344 Eggenstein-Leopoldshafen, Germany (fax: (+49) 7247-808-666, e-mail: crysdata@fiz-karlsruhe.de/request_for_deposited_data.html) for deposition number CSD427573. A complete list of bond distances and angles are provided in table format. The FourierTransform Infrared (FTIR-ATR) spectrum of $\mathrm{Tc}_{2}\left(\mathrm{O}_{2} \mathrm{CCH}_{3}\right)_{4} \mathrm{I}$ is shown with a list of frequencies as well as magnetic susceptibility data. Supplementary data associated with this article can be found, in the online version, at (http:// web address).

\section{References}


${ }^{1}$ (a) F. A. Cotton, C. A. Murillo, R. A. Walton, Multiple Bonds between Metal Atoms, $3^{\text {rd }}$ ed., F. A. Cotton, C. A. Murillo, R. A. Walton (eds.), Springer, NY, 2005, chap. 1. (b) J. H. Canterford, R. Colton, Halides of the Second and Third Row Transition Metals, John Wiley and Sons, NY, 1968. (c) F. A. Cotton, G. Wilkinson, C. A. Murillo, M. Bochmann, Advanced Inorganic Chemistry, $6^{\text {th }}$ ed., John Wiley and Sons, NY, 1999. (d) N. Shtemenko, P. Collery, A. Shtemenko, Anticancer Res. 2007, 27, 2487. (e) G. Hogarth, Organomet. Chem. 1995, 24, 184. (f) D. J. Timmons, M. P. Doyle, Multiple Bonds between Metal Atoms, $3^{\text {rd }}$ ed., F. A. Cotton, C. A. Murillo, R. A. Walton, R. A. (eds.), Springer, NY, 2005, chap. 13. (g) E. L. Muetterties, M. J. Krause, Angew. Chem. Int. Ed. 1983, 22, 135.

2 (a) J. F. Berry, Multiple Bonds between Metal Atoms, $3^{\text {rd }}$ ed., F. A. Cotton, C. A. Murillo, R. A. Walton (eds.), Springer, NY, 2005, chap. 15. (b) M. H. Chisholm, A. M. Macintosh, Chem. Rev. 2005, 105, 2949. (c) J. Lin, G. J. Miller, Inorg. Chem. 1993, 32, 1476-1487. (d) B. H. S.

Thimmappa, Coord. Chem. Rev. 1995, 143, 1-34.

${ }^{3}$ A. P. Sattelberger, Multiple Bonds between Metal Atoms, Chapter 7, $3^{\text {rd }}$ Ed., F. A. Cotton, C. A. Murillo, R. A. Walton (Eds), Springer, New York 2005, chap 7.

${ }^{4}$ P. F. Weck, E. Kim, F. Poineau, E. Rodriguez, A. P. Sattelberger, K. R. Czerwinski, Inorg. Chem. 2009, 48, 6555.

${ }^{5}$ F. Poineau, E. E. Rodriguez, P. M. Forster, A. P. Sattelberger, A. K. Cheetham, K. R. Czerwinski, J. Am. Chem. Soc. 2009, 131, 910.

${ }^{6}$ F. Poineau, C. D. Malliakas, P. F. Weck, B. L. Scott, E. V. Johnstone, P.M. Forster, E. Kim, M. G. Kanatzidis, K. R. Czerwinski, A. P. Sattelberger, J. Am. Chem. Soc. 2011, 133, 8814.

${ }^{7}$ F. Poineau, E. V. Johnstone, P. F. Weck, E. Kim, P. M. Forster, B. L. Scott, A. P. Sattelberger, K. R. Czerwinski, J. Am. Chem. Soc. 2010, 132, 15864.

${ }^{8}$ E. V. Johnstone, F. Poineau, J. Starkey, T. Hartmann, P. M. Forster, L. Ma, J. Hilger, E. E. Rodriguez, K. R. Czerwinski, A. P. Sattelberger, Inorg. Chem. 2013, 52, 14309.

${ }^{9}$ F. Poineau, E. V. Johnstone, K. R. Czerwinski, A. P. Sattelberger, Acc. Chem. Res. 2014, 47, 624.

${ }^{10}$ K. Schowchau, Technetium: Chemistry and Radiopharmaceutical Applications; Wiley-VCH: Weinheim, Germany, 2000.

${ }^{11}$ T. K. Todorova, F. Poineau, P. M. Forster, L. Gagliardi, K. R. Czerwinski, A. P. Sattelberger, Polyhedron 2014, 70, 144.

${ }^{12}$ P. A. Koz'min, T. B. Larina, M. D. Surazhskaya, Koord. Khim. 1981, 7, 1719.

${ }^{13}$ P. A. Koz'min, T. B. Larina, M. D. Surazhskaya, Koord. Khim. 1983, 9, 1114. 
${ }^{14}$ L. Zaitseva, A. Kotel'nikova, A. Reszvov, Russ. J. Inorg. Chem. 1980, 25, 1449.

${ }^{15}$ W. M. Kerlin, F. Poineau, K. R. Czerwinski, P. M. Forster, A. P. Sattelberger, Polyhedron 2013, 58, 155.

${ }^{16}$ R. Busey, R. Bevan, R. Gilbert, J. Chem. Thermodynamics 1972, 4, 77.

${ }^{17}$ Sheldrick, G. M. Acta. Cryst. A. 2008, 64, 112.

${ }^{18}$ O. V. Dolomanov, L. J. Bourhis, R. J. Gildea, J. A. K. Howard, H. Puschmann, OLEX2: A Complete Structure Solution, Refinement and Analysis Program. J. Appl. Cryst. 2009, 42, 339.

${ }^{19}$ C. F. Macrae, I. J. Bruno, J. A. Chisholm, P. R. Edgington, P. McCabe, E. Pidcock, L. Rodriguez-Monge, R. Taylor, J. van de Streek and P. A. Wood, J. Appl. Cryst. 2008, 41, 466.

20 Environmental Protection Agency Environmental Monitoring and Support Laboratory Office of Research and Development. 1979. USA EPA method 345.1. Methods for chemical analysis of water and wastes. Environmental Protection Agency, Cincinnati, Ohio.

${ }^{21}$ V. I. Spitsyn, B. Baierl, S. V. Kryuchkov, A. F. Kuzina and M.Varen, Dokl. Akad. Nauk. 1981, 256,608 .

${ }^{22}$ S. V. Kryuchkov, A. F. Kuzina, V. I. Spitsyn, Dokl. Chem. 1982, 266, 304.

${ }^{23}$ V. Kryuchkov, Topics in Current Chemistry 1996, 176, 189.

${ }^{24}$ S. V. Kryuchkov, A. F. Kuzina, V. I. Spitsyn, Dokl. Chem. 1982, 266, 127.

${ }^{25}$ P. Angaridis, Multiple Bonds between Metal Atoms, $3^{\text {rd }}$ Ed., F. A. Cotton, C. A. Murillo, R. A. Walton (Eds), Springer, New York 2005, chap 9.

${ }^{26}$ T. Togano, M. Mukaida, T. Nomura, Bull. Chem. Soc. Jpn. 1980, 53, 2085.

${ }^{27}$ T. Kimura, T. Sakurai, M. Shima, T. Togano, M. Mukaida, T. Nomura, Bull. Chem. Soc. Jpn. 1982, 55, 3927.

${ }^{28}$ R. A. Walton, Multiple Bonds between Metal Atoms, $3^{\text {rd }}$ Ed., F. A. Cotton, C. A. Murillo, R. A. Walton (Eds), Springer, New York 2005, chap 8.

${ }^{29}$ F. A. Cotton, L. D. Gage, C. E. Rice, Inorg. Chem. 1979, 18, 1138.

${ }^{30}$ F. A. Cotton, L. D. Gage, Nouv. J. Chim. 1977, 1, 441.

${ }^{31}$ F. Poineau, P. M. Forster, T. K. Todorova, L. Gagliardi, A. P. Sattelberger, K. R. Czerwinski, Dalton Trans. 2012, 41, 2869. 
${ }^{32}$ A. F. Cotton, K.R. Dunbar, L. R. Falvello, M. Tomas, R. A. Walton, J. Am. Chem. Soc. 1983, $105,4950$.

${ }^{33}$ Y. V. Rakitin, S. V. Kryuchkov, A.I Aleksandrov, A. F. Kuzina, N. V. Nemtsev, B. G. Ershov, V. I. Spitsyn, Dokl. Akad. Nauk. SSSR, 1983, 269, 1123.

${ }^{34}$ P. Pyykko, M. Atsumi, Chem. Eur. J. 2009, 15, 12770.

${ }^{35}$ R. A. Wheeler, R. Hoffman, J. Am. Chem. Soc. 1986, 108, 6605.

${ }^{36}$ M. S. Grigoriev, S. V. Kryuchkov, Radiochim. Acta 1993, 63, 187.

${ }^{37}$ S. S. Batsanov, Inorg. Mat. 2001, 37, 871.

${ }^{38}$ P. A. Koz'min, M. D. Surazhskaya, T. B. Larina, Dokl. Phys. Chem. 1982, 265, 656.

${ }^{39}$ S. V. Kryuchkov, A. F. Kuzina, V. I. Spitsyn, Dokl. Chem. 1986, 287, 1400.

${ }^{40}$ V. I. Spitzin, S. V. Kryuchkov, M. S. Grigoriev, A. F. Kuzina, Z. Anorg. Allg. Chem. 1988, $563,136$.

${ }^{41}$ S. V. Kryuchkov, M. S. Grigoriev, A. F. Kuzina, B. F. Gulev, V. I. Spitsyn, Dokl. Chem. 1986, $288,172$. 


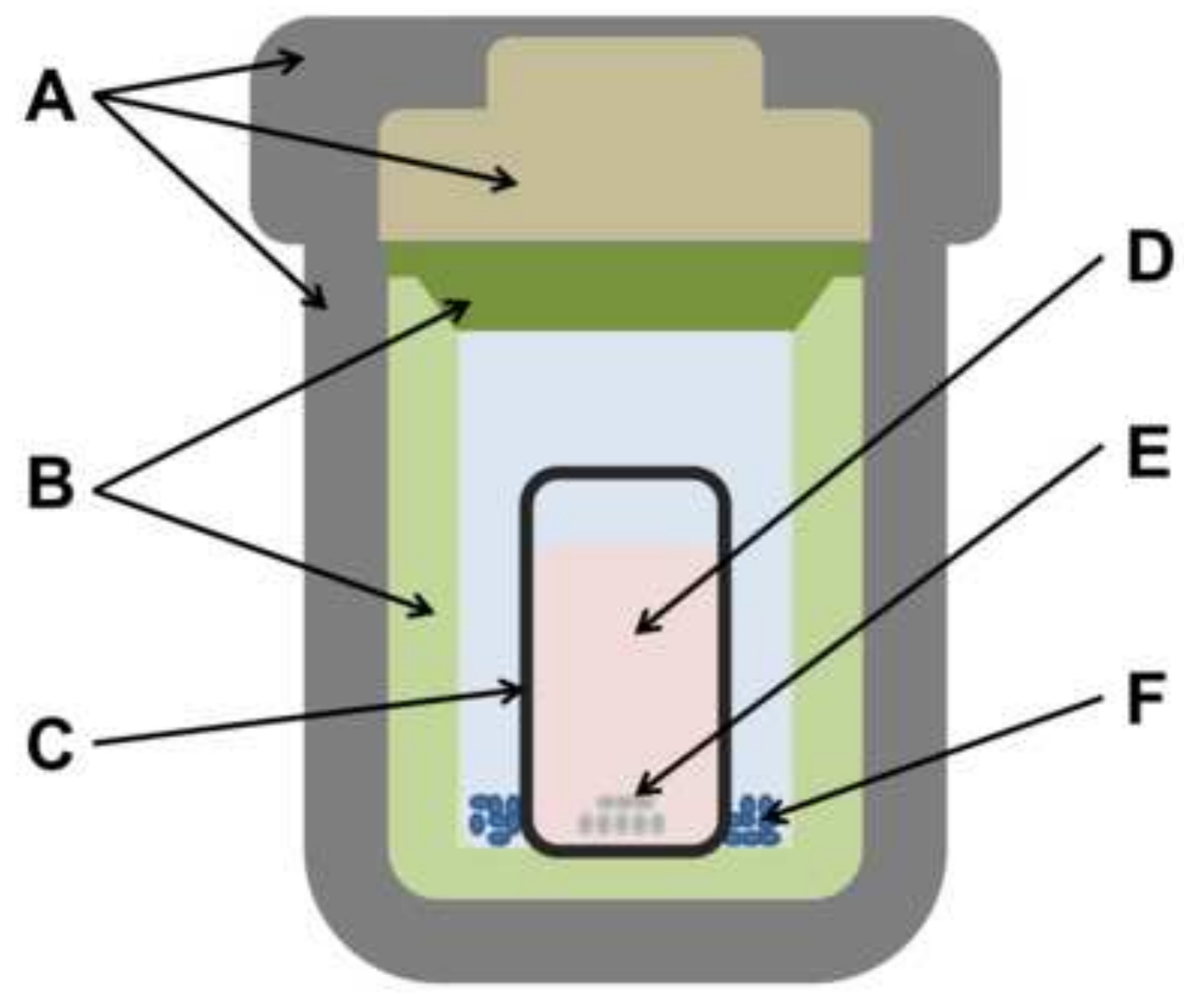




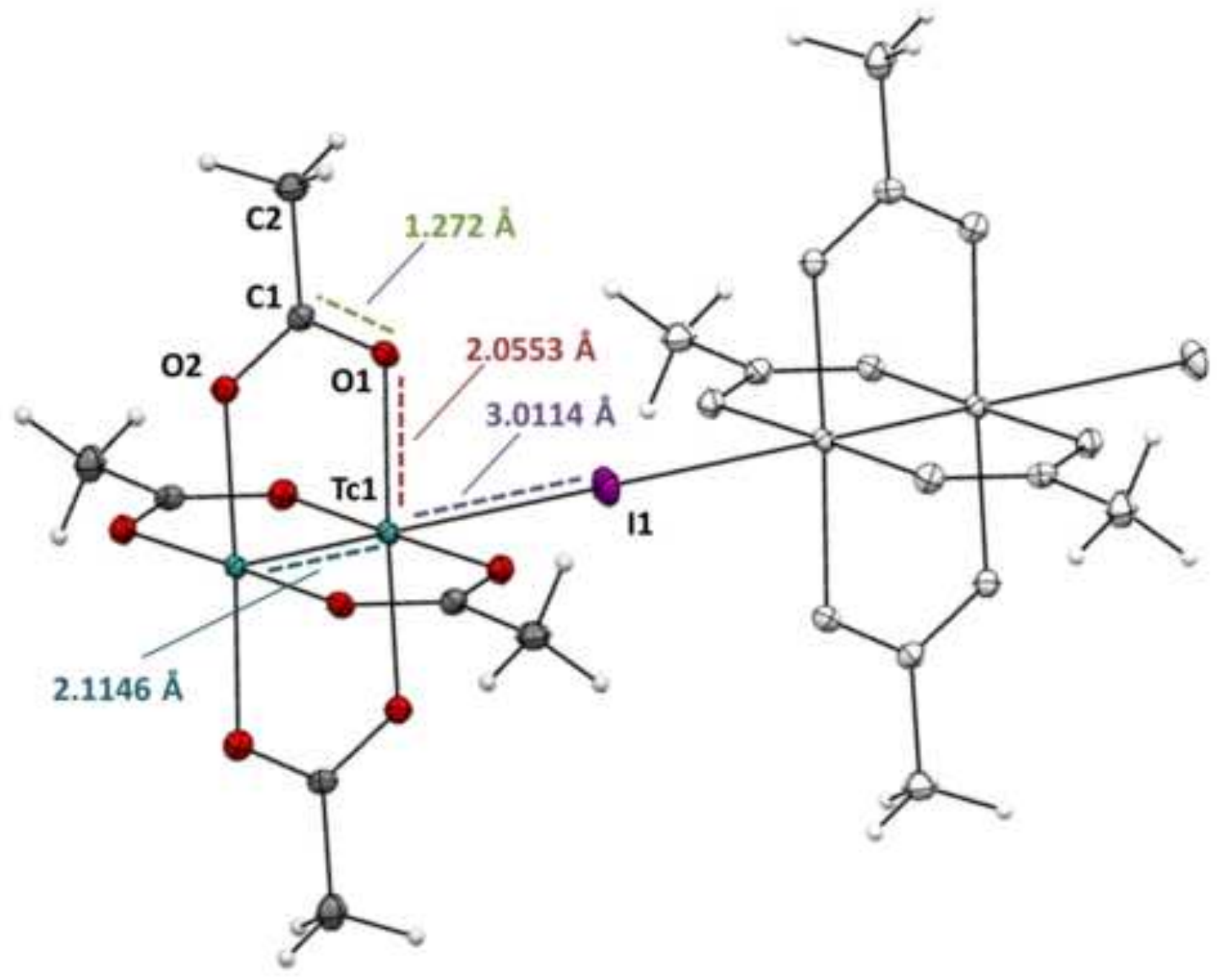



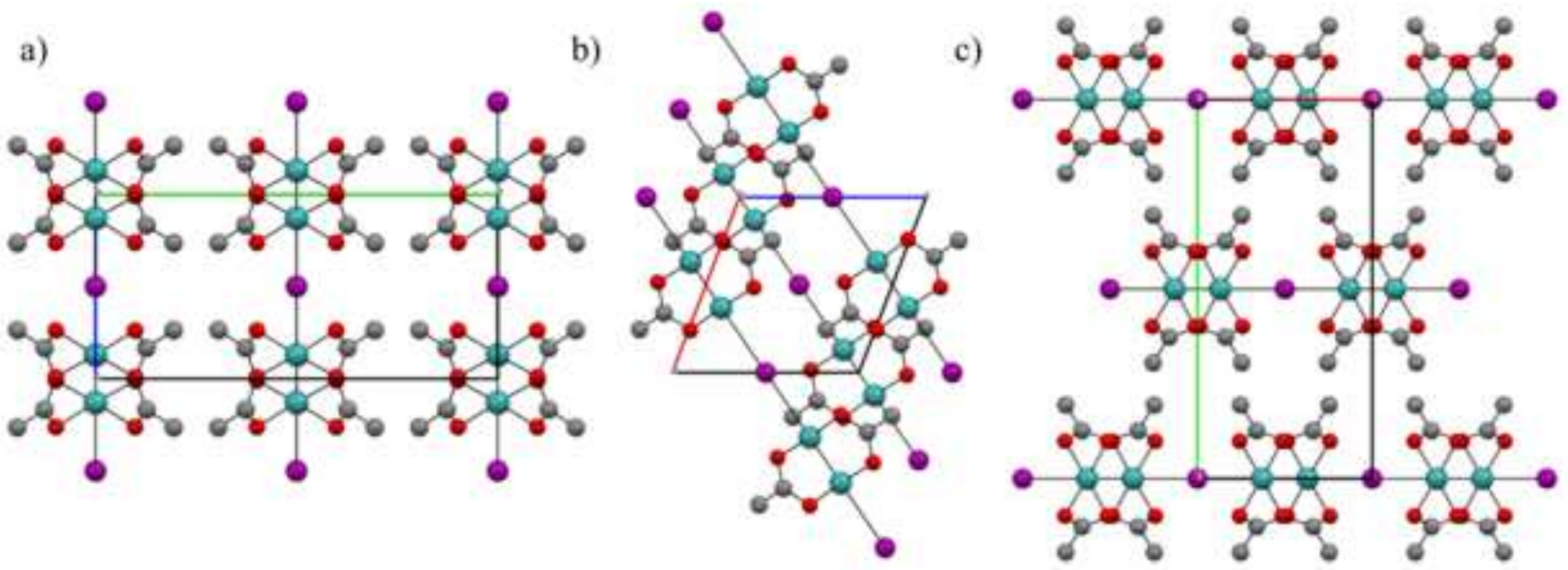


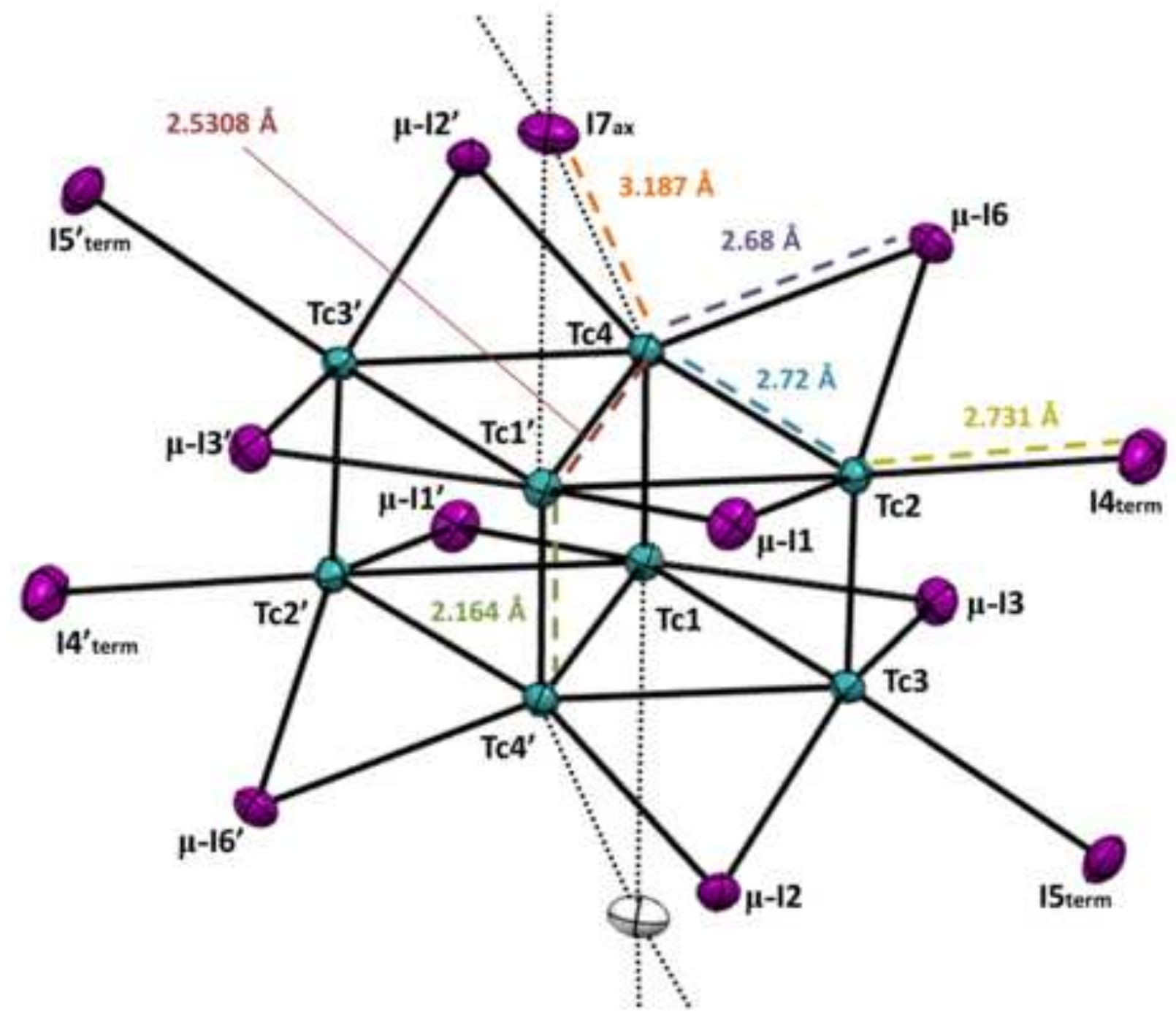



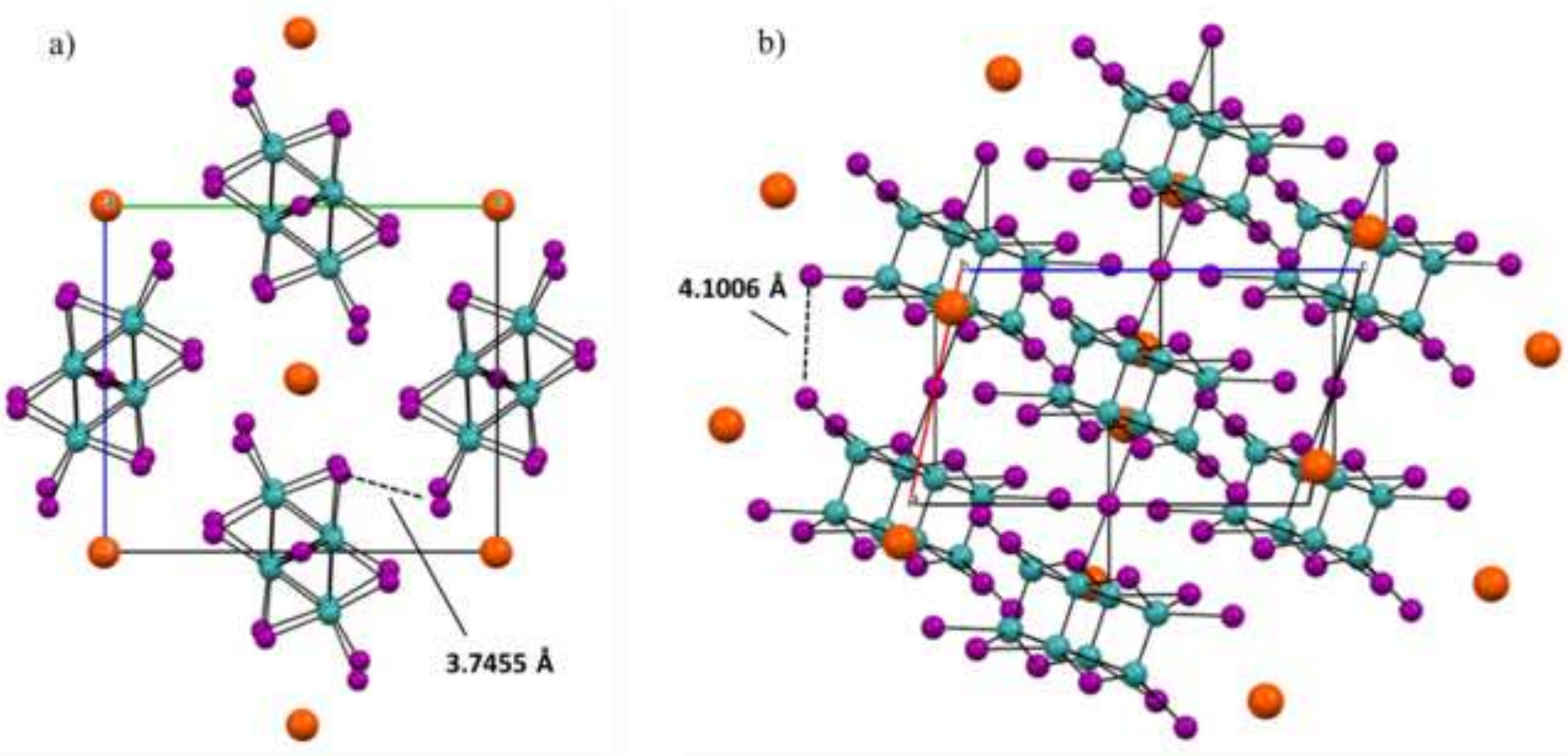